\title{
Unpredicted occurrence of Aglae caerulea in the Pantanal wetland biome and its implications (Apidae: Euglossini)
}

\author{
Evandson J. ANJos-SiLVA
}

Neotropical Bees and Wasps Laboratory, Department of Biology, University of Mato Grosso State, Av. Tancredo Neves 563, Cáceres, MT, Brazil

Received 18 July 2018 - Revised 19 February 2019 - Accepted 5 March 2019

\begin{abstract}
An unpredicted occurrence of the cleptoparasitic orchid bee Aglae caerulea is announced for the Pantanal wetland biome in midwest Brazil, cataloged in a gallery forest in the Serra das Araras Ecological Station, southwestern Mato Grosso. A single female was cataloged outside the polygons where surveys were recently proposed for new orchid bee inventories in the Neotropical realm. The female found in habitat preoccupied by its hostess Eulaema nigrita is presumed representative to confirm that $A$. caerulea occurs in sympatry with their host in this wetland. Two recent points of occurrence in the Amazon rainforest of Mato Grosso were included here to update the Aglae distribution map. Following a meticulous literature review, several previous records from tropical moist forests in Panama and spanning from the Caribbean Sea to the Cerrado in central Bolivia and Brazil were used to complete the present record points of A. caerulea in the neotropics. The results demonstrate another distributional gap in euglossines and suggest the need for additional studies to find Aglae in southern Pantanal and farther afield.
\end{abstract}

\section{neotropics / Hymenoptera / orchid bees / gallery forest / Cerrado}

Neotropical orchid bees include the pollen-collecting genera Eufriesea Cockerell, Euglossa Latreille, and Eulaema Lepeletier, and two parasitic genera, Exaerete Hoffmannsegg and Aglae Lepeletier de Saint-Fargeau and Audinet-Serville (Michener 2007). The latter is monotypic and represented by Aglae caerulea Lepeletier de Saint-Fargeau and Audinet-Serville (body size 20-28 $\mathrm{mm}$ ), which emerge from the nests of Eulaema nigrita Lepeletier (Myers 1935) (body size 18-31 mm), on which they depend for shelter and provisions for larvae.

Euglossine males are attracted to chemical baits, whereas the females have only been sighted and collected by entomologists when visiting blossoms or netted mid-flight (Dressler 1982), or with the help of trapnests (Garófalo et al. 1993).

Moure (1967) and Cameron (2004) identified A. caerulea as endemic to the Amazon basin (see Morato 2001), however, Anjos-Silva et al. (2006), Silva

Corresponding author: E. Anjos-Silva, evandson@unemat.br

Manuscript editor: Klaus Hartfelder et al. (2013), and Martins et al. (2016) reported occurrences for the Cerrado domain. More recently, our team has collected A. caerulea in two study areas in the northern Mato Grosso Amazon, in Cotriguaçu (Schorn de Souza 2014) and Novo Mundo (Figueiredo 2015).

I report here an unpredicted occurrence of A. caerulea on the northern border of the Pantanal wetland, in southwestern Mato Grosso. Several biogeographical implications of this are discussed, and additional studies suggested for testing the distribution limits in southern Pantanal and farther afield.

\section{MATERIAL AND METHODS}

\subsection{Study area}

The study was conducted in the Serra das Araras Ecological Station, a permanently protected 28,700-ha area of parallel mountain ranges running from the northwest to the southeast (NE-SE), 50-km-long and 8-kmwide (elevation from 230 to $900 \mathrm{~m}$ ), located in the Porto Estrela municipality, southwestern Mato Grosso (Figure 1, 


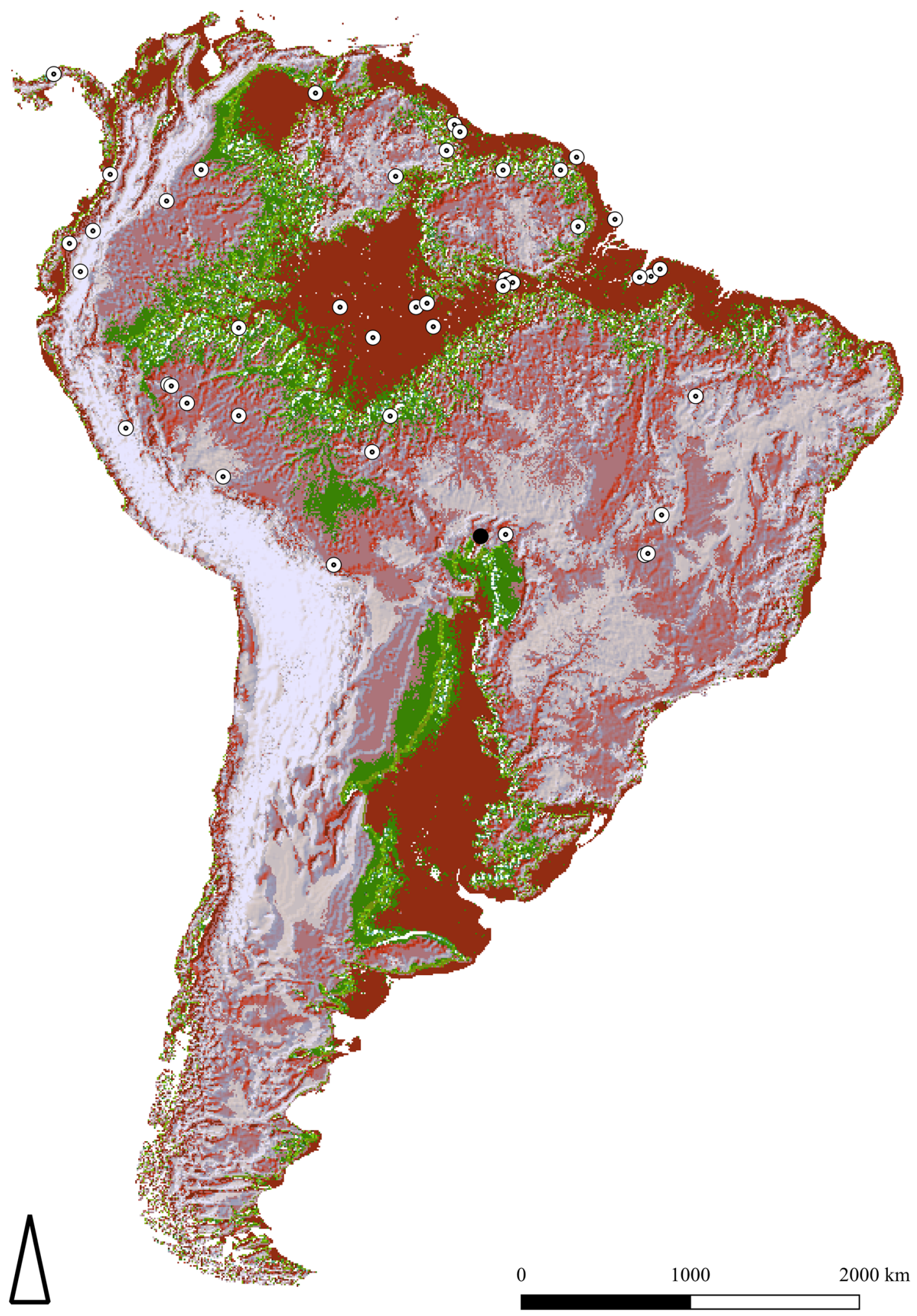


Figure 1 Distribution of the 70 occurrences for Aglae caerulea in the Neotropics, from $10^{\circ} \mathrm{N}$ in northern Venezuela (Aragua) and $8^{\circ} \mathrm{N}$ Panama to $17^{\circ} \mathrm{S}$ in central Bolivia (Cochabamba) and $16^{\circ} \mathrm{S}$ in central Brazil (Mato Grosso and Goiás). Circles refer to the previous A. caerulea's known records. Arrow refers to the newest record (this study) in the Serra das Araras Ecological Station, at the northern border of the Pantanal wetland biome, Porto Estrela municipality, Mato Grosso, Brazil.

black circle). The ecological station is controlled by the ICMBio Instituto Chico Mendes de Conservação da Biodiversidade of Brazil. The gallery forest studied is composed of trees with a height of ca. 5-10 m and is situated at the margins of the Salobra stream, in an upstream basin area ca. $20 \mathrm{~km}$ west of the Pantanal floodplain (EJ Anjos-Silva personal observation).

\subsection{Specimen collection}

Throughout the field study period, insects were netted daily for 7 days from 27 April to 3 May 2017. Entomological nets, McPhail traps, and 2-L plastic bottles were used to collect wild bees and wasps in four different canopies along four ecological trails at the same time at this ecological station (unpubl. data). One female was collected near the headquarters of the ecological station $\left(15^{\circ} 39.00^{\prime} \mathrm{S}-57^{\circ} 12.00^{\prime} \mathrm{W}\right.$; elevation $\left.230 \mathrm{~m}\right)$, in an entomological net, sacrificed in ethyl acetate and deposited (voucher EJASC 77.000) at the Neotropical Bees and Wasps Laboratory at UNEMAT, University of Mato
Grosso State, Brazil. The expeditions had been granted permission to collect insects under ICMBio SisBio license numbers 12.778 and 53.717 in the name of EJAS.

\subsection{Species occurrences}

Curiously, following a meticulous literature review, I noted that we (Anjos-Silva et al. 2006; Silva et al. 2013) had previously disregarded some studies: Beebe (1951), Bonilla-Gómez and Nates-Parra (1992), González (1996), Bembé (2002), Hentrich et al. (2007), and Abrahamczyk et al. (2011a, b). Further collection sites were also obtained from Martins et al. (2016), the GBIF Global Biodiversity Information Facility (www.gbif.org), the Discover Life Bee Species Guide and World Checklist (Ascher and Pickering 2018) (http://www.discoverlife.org), and CRIA's Species Link (www.splink.org.br).

\section{RESULTS}

The female A. caerulea was observed in the gallery forest, landing only once on the leaf bush of an undetermined species of Fabaceae, viz. on 1 May 2017 in a trail near the headquarters of the ecological station (Figure 1). At about 10:15 a.m., the female approached the bush leaf and landed on it for approximately $10 \mathrm{~s}$ before being collected.

This finding of A. caerulea in the northern Pantanal border region has several biogeographical implications: (a) this record represents a very distinctive biota to consider in future search expeditions for this species,

Table I.. Köppen-Geiger climate zones and associated geographic distribution pattern for the parasitic orchid bee Aglae caerulea and its Eulaema nigrita hostess in the Neotropics. Three other Eulaema species (cf. Oliveira 2007; Ascher and Pickering 2018) E. bombiformis (Packard 1869), E. cingulata (Fabricius 1804), and E. meriana (Olivier 1789) occur in sympatry with $E$. nigrita nest parasites at least from $10^{\circ} \mathrm{N}$ to $15^{\circ} \mathrm{S}$ in the neotropics encompassing the Amazon and Atlantic rainforest to Cerrado biomes.

Euglossini species $\quad$ Biomes and Köeppen-Geiger climate types ${ }^{1}$

\begin{tabular}{|c|c|c|c|c|c|c|c|}
\hline & \multicolumn{3}{|c|}{ Tropical rainforest } & \multicolumn{3}{|c|}{ Atlantic rainforest } & \multirow{2}{*}{$\begin{array}{c}\text { Tropical savannah } \\
\text { Aw }\end{array}$} \\
\hline & Af & $\mathrm{Am}$ & Aw & Af & $\mathrm{Am}$ & Aw & \\
\hline Aglae caerulea & $*$ & $*$ & $*$ & ? & $?$ & $?$ & $*^{2}$ \\
\hline Eulaema nigrita & $*$ & $*$ & $*$ & $*$ & $*$ & $*$ & $*$ \\
\hline Eulaema bombiformis & $*$ & $*$ & $*$ & $*$ & $*$ & $*$ & $*$ \\
\hline Eulaema cingulata & $*$ & $*$ & $*$ & $*$ & $*$ & $*$ & $*$ \\
\hline Eulaema meriana & $*$ & $*$ & $*$ & $?$ & $*$ & $*$ & $*$ \\
\hline
\end{tabular}

\footnotetext{
${ }^{1}$ Köppen-Geiger climate classifications follow Peel et al. (2007). Af, tropical rainforest climate; $A m$, tropical monsoon climate; $A w$, tropical wet and dry or savannah climate. ${ }^{*}=$ presence of species.? = species not cataloged until today

2 This study
} 
(b) new data cataloging presence in habitats not indicated in any studies, through sampling or species distribution modeling, (c) the possibility that $A$. caerulea is able to explore different plant species as food and shelter resources in the wetland biome, (d) expansion of the species distribution limits forming a "new" suitable area, (e) it corroborates the hypothesis that the species is as locally rare in floodplains as it is elsewhere, and (f) it confirms that this parasitic species occurs in sympatry with its hostess E. nigrita in the Pantanal biome.

Although our result is based on a singleton, it is considered representative to confirm that this parasitic species lives not only in sympatry with its hostess E. nigrita but also in the Pantanal and of sufficient size to encourage new expeditions to find Aglae in southern Pantanal and farther afield.

It is necessary to highlight three issues: (a) the climate of the areas where A. caerulea has been cataloged in the Amazon varies from tropical rainforest climate (Af) to tropical monsoon climate (Am), according to the Köppen-Geiger classification (cf. Peel et al. 2007, Table I), (b) using distribution modeling, Silva et al. (2013) indicated the region stretching from north Espírito Santo to north Bahia as a potentially suitable area for A. caerulea, and (c) the Aw category corresponds to the climate of the Pantanal (Table I).

The present study reveals another distributional gap in euglossine "rainforest-dependent species," but demonstrates that new experiments are needed to confirm whether A. caerulea uses gallery forests to cross the Cerrado ecocline toward the Amazon and to reach Atlantic rainforest habitats. This hypothesis requires testing to determine whether or not the absence of this cleptoparasitic species in rainforest fragments of Brazil's Atlantic coast is a technical artifact.

\section{ACKNOWLEDGMENTS}

Support was provided by FAPEMAT (project numbers 334721/2008, 737955/2012, 222842/2015). Thanks for the field assistance provided by INCT/CENBAM/PPBio/ UFMT/UNEMAT to MH Schorn de Sousa and JDS Figueiredo, and INCT PPBIO/INPA/UNEMAT to EJAS. Thanks to Lourivaldo A. Castro for the map design. Thanks Dr. Carlos A. Garófalo (USP), for suggestions. The author thanks the reviewers for their invaluable help.

\section{AUTHOR CONTRIBUTION}

EJAS conceived, designed, and performed this research and interpretation of the data and wrote the paper. The author read and approved the final manuscript.

\section{O M P L I A N C E W I T H ETH I CAL STANDARDS}

Conflict of interest The author declares that there are no conflicts of interest.

\section{Note scientifique: occurrence imprévue D' aglae caerulea dans les zones humides du Pantanal et ses implications (Apidae: Euglossini)}

Les néotropiques / Hymenoptera / abeilles à orchidée / forêt galerie / cerrado

\section{Wissenschaftliche Notiz: Unvorhergesehenes Vorkommen von Aglae caerulea im Pantanal Sumpfgebiet und seine Implikationen (Apidae: Euglossini)}

\section{Neotropen / Hymenoptera / Prachtbienen / Galeriewald / Cerrado}

\section{REFERENCES}

Abrahamczyk, S., Gottleuber, P., Matauschek, C., Kessler, M. (2011a) Diversity and community composition of euglossine bee assemblages (Hymenoptera: Apidae) in western Amazonia. Biodivers. Conserv. 20; 2981-3001

Abrahamczyk, S., Gottleuber, P., Kessler, M. (2011b) Seasonal changes in odour preferences by male Euglossine bees (Hymenoptera: Apidae) and their ecological implications. Apidologie. 43, 212-217

Anjos-Silva, E.J., Camillo, E., Garófalo, C.A. (2006) Occurrence of Aglae caerulea Lepeletier and Serville (Hymenoptera: Apidae: Euglossini) in the Chapada dos Guimarães National Park, Mato Grosso state, Brazil. Neotrop Entomol. 35, 868870

Ascher, J., Pickering, J. (2018) Discover Life bee species guide and world checklist (Hymenoptera: Apoidea: Anthophila). $\mathrm{http}: / /$ www.discoverlife.org $/ \mathrm{mp} / 20 \mathrm{q}$ ?guide=Apoidea_species. Accessed 01 May 2018

Beebe, W. (1951) Migration of Nymphalidae (Nymphaline), Brassolidae, Morphidae, Libytheidae, Satyricidae, Riodinidae, Lycaenidae and Hesperidae (Butterflies) Through Portachuelo Pass, Rancho Grande, North-central Venezuela. Zoologica. 36, $1-16$

Bembé, B. (2002) Prachtbienenfunde aus Panguana, Huánuco, Peru (Hymenoptera: Apidae: Euglossini). Spixiana. 25, 245-249

Bonilla-Gómez, M.A., Nates-Parra, G. (1992) Abejas euglosinas de Colombia (Hymenoptera: Apidae) I. Claves ilustradas. Caldasia. 17, 149-172 
Cameron, S.A. (2004) Phylogeny and biology of neotropical orchid bees (Euglossini). Annu Rev Entomol. 49, 377-404

Dressler, R.L. (1982) Biology of the orchid bees (Euglossini). Annu Rev Ecol Syst. 13, 373-379

Fabricius, J.C. (1804). Systema Piezatorum secundum ordines, genera, species, adjectis synonymis, locis, observationibus, descriptionibus. Brunsvigae: Reichard 1-439 pp

Figueiredo, J.D.S. (2015) Estrutura da comunidade de abelhas-dasorquídeas (Hymenoptera: Apidae: Euglossini) na Floresta Amazônica do Parque Estadual Cristalino, Mato Grosso. Dissertation, Universidade do Estado de Mato Grosso

Garófalo, C.A., Camillo, E., Serrano, J.C., Rebêlo, J.M.M. (1993) Utilization of trap nests by Euglossini species Hymenoptera: Apidae. Rev Bras Biol. 53, 177-187

González, J.M. (1996) Fauna del Parque Nacional "Henri Pittier": Euglossini (Hymenoptera: Apidae: Bombinae). Claves y lista preliminar. Soc Ciênc Nat La Salle. 145, 45-54

Hentrich, H., Kaiser, R., Gottsberger, G. (2007) Floral scent collection at the perfume flowers of Anthurium rubrinervium (Araceae) by the kleptoparasitic orchid bee Aglae caerulea (Euglossini). Ecotropica. 13, 149155

Martins, D.C., Albuquerque, P.M.C., Silva, F.S., Rebêlo, J.M.M. (2016) First record of Aglae caerulea (Hymenoptera, Apidae, Euglossini) in Brazilian Cerrado east of the Amazon Region, Maranhão State, Brazil. Braz J Biol. 76, 554-556.

Michener, C.D. (2007) The Bees of the World. 2nd edn. Johns Hopkins University Press, Baltimore

Morato, E.F. (2001) Ocorrência de Aglae caerulea Lepeletier and Serville (Hymenoptera, Apidae, Apini, Euglossina) no estado do Acre, Brasil. Rev Bras Zool. 18, 1031-1034
Moure, J.S. (1967) A check-list of the know euglossine bees (Hymenoptera, Apidae). Atas Simp Biota Amazônica. 5, 395-415

Myers, J.G. (1935) Ethological observations on the citrus bee Trigona silvestriana Vachal and other neotropical bees (Hym., Apoidea). Trans R Entomol Soc Lond. 83, 131-142

Olivier, A.G. (1789) Abeille pp. 46-84 in M.M. Diderot \& D' Alembert (ed.) Encyclopédie Métodique. Histoire Naturelle. Insectes Vol. 4. Paris: Pankouke 331 pp

Oliveira, M.L. (2007) Catálogo comentado das espécies de abelhas do gênero Eulaema Lepeletier, 1841 (Hymenoptera: Apidae). Lundiana. 8, 113-136

Packard, A.S. Jr. (1869) List of hymenopterous and lepidopterous insects collected by the Smithsonian Expedition to South America, under Prof. James Orton. Annu. Rep. Peabody Acad. Sci. 1, 52-69

Peel, M.C., Finlayson, B.L., Mcmahon, T.A. (2007) Updated world map of the Köppen-Geiger climate classification. Hydrol Earth Syst Sci. 4 , 439-493

Schorn de Souza, M.H. (2014) Estrutura e composição da comunidade de abelhas Euglossini atraídas por iscas artificiais na Amazônia Meridional, Brasil. Dissertation, Universidade Federal de Mato Grosso.

Silva, D.P., Aguiar, A.J.C., Melo, G.A.R., Anjos-Silva, E.J., De Marco, P. Jr. (2013) Amazonian species within the Cerrado savanna: new records and potential distribution for Aglae caerulea (Apidae: Euglossini). Apidologie. 44, 673-683

Publisher's note Springer Nature remains neutral with regard to jurisdictional claims in published maps and institutional affiliations. 